\title{
Electronic platforms as a new ecosystem of the organization and the conduct of business ${ }^{a}$
}

\author{
Roman Jaque ${ }^{1 *}$, Marat Sarygulov ${ }^{2}$, and Joao Leitao ${ }^{3}$ \\ ${ }^{1}$ Saint-Petersburg State University, Economics dept., 199034 University emb. 7/9, Russian \\ Federation \\ ${ }^{2}$ Saint-Petersburg University of Technologies of Management and Economy, Institute of Economy, \\ Management and Information Technologies, 190103, Lermontov pr. 44A, Russian Federation \\ ${ }^{3}$ Universidade da Beira Interior (UBI), P-6200-001, Portugal
}

\begin{abstract}
At the present moment, leading industrial countries and such new and quickly growing economies as China and India that also actively use the possibilities provided by new technological platforms, form a new type economy known as "digital economy" or "economy of joint use". As the new technological platform is based on information technologies, the best synergetic effect is achieved through using electronic platforms, with their number and variety quickly growing, so they are actually creating a new infrastructure for communication between the primary economic agents. A new ecosystem also provides new possibilities, including instrumental ones, for conduct of business, searching for jobs and developing the business environment. This article analyzes new trends in development of business in the conditions of a newly forming digital economy.
\end{abstract}

\section{Introduction}

Since the beginning of this century, a particular feature of technological development is quick industrial implementation of micro-level technologies. This offered such possibilities as: firstly, creating digital infrastructure (the Internet, cell phones, smartphones) that is, practically, affordable for every customer and, secondly, the actual timely and addressed answer to customers' requirements. For example, such leaders of the digital industry as Facebook, YouTube and WhatsApp had, respectively, 1.59 billion and 1.0 billion active users in March 2016 [1], whereas as soon as in June 2017, this number grew to 2.0, 1.5 and 1.2 billion users, respectively [2]. Another spectacular example is quick growth in the volume of electronic (on-line) trade that was only made possible in the conditions of the widely-spread Internet. Starting from 1995, the volume of the world trade has been constantly growing and had reached USD 50 billion by 2000 ; by 2010 , this volume had reached USD 250 billion [3]. The latest research showed that, in 2017, this figure was USD 2.3 trillion, and by 2021 the volume of the world electronic trade is expected to reach the

\footnotetext{
*Corresponding author: zhak55@ya.ru

${ }^{a}$ This article was prepared with financial support from the Russian Scientific Fund (Grant No. 18-1800099)
} 
level of USD 4.5 trillion [4]. A constituent part of this process is development of on-line banking. For example, in the USA in 2000, this service was used by 16 million homes, and 10 years later this figure was 52 million homes [3]. A research carried out in 2015 in Europe showed that two-thirds of customers make purchases using a PC or a notebook, and $15 \%$ use smartphones [5]. Such wide coverage of customers and a very quick growth in the number of users means that digital technologies create radically new possibilities for commercial communication and meeting customers' demands, which is most important for conduct of business.

At the same time, electronic platforms, while quickly reacting to customers' needs, create conditions (on the competition basis) for removing separate professional groups from the market. A classic example is the company Uber who deal in transportation - not possessing a single vehicle of their own or employing a single driver, in 2014 it provided jobs for 160 thousand drivers, and the volume of capitalization of the company was evaluated as USD 41 billion [6]. In 2016, the company already had 50 million users in 450 cities and 78 countries, and cooperated with 7 million partner-drivers who provided 50-60 million journeys per month, with the net yearly profit of the company reaching USD 6.5 billion and capitalization of USD 48 billion [7]. Having a flexible time-schedule, drivers working with this company provide cheaper services with a better quality, while receiving higher income than the taxi drivers employed on the permanent basis. As the research of the activity of the company Uber in the USA showed, the average hourly pay for the drivers with the company is USD 19, as compared to USD 13 for professional taxi drivers [8]. Such significant difference in the level of income causes changes in the structure of the jobs market, especially considering that, in every segment, companies are formed who follow the ideology of Uber. To name a few, there are such companies as TaskRabbit and Handy (personal and household services), Freelancer and Upwork (business services), Instacart and Postmates (delivery services), Heal and Pager (medical services).

One of the significant consequences of the wide use of digital technologies is the change in the character of work and the structure of employment. The process of "digitalization" not only allows accelerating various processes in the economy as a whole but also provides new possibilities to select the form of organizing own work for representatives of many professions without being tied to the classic scheme "employer-employee". An analysis of the American jobs market showed a significant growth in the number of workers using alternative forms of employment - during the period 2005 to 2015 , this share in the total number of employees had grown from $10.1 \%$ to $15.8 \%$ (14.2 million to 23.6 million employees) [9]. Speaking of the "contingent" workers segment (partially employed, selfemployed, freelancers, temporary and unqualified workers), their share in the total number of workers is evaluated at the present as about $40 \%$ and is expected to become $50 \%$ by 2030 [10]. Obviously, such changes should be considered by businessmen and will affect business activities.

\section{Electronic platforms}

Quick development of the Internet and the electronic trade stimulated economic research to achieve a better understanding of the economic essence of these processes. In this regard, it should be noted that electronic platforms were found to be the primary element of the forming new system. Despite that economic literature offers various definitions for the term "electronic platform", we will highlight those few that, in our opinion, best describe this new element of the economic system. Firstly, the "two-sided" platforms were examined, whose purpose is ensuring that both parties reduce their expenditures for finding partners and communicating in the process of obtaining profit from trade [11]. In the evolution plane, this definition further developed the approaches previously adopted in the economic 
literature [12]. Further development of two-sided platforms showed that such basic functions of theirs as minimizing expenses, creating "public sites" and finding business partners tend to expand. As a result of such development, more complicated multi-scale platforms were created, with two basic characteristics: to enable direct communication between two or more parties, with each party having a direct connection with the platform [13]. In 2015, the European Commission gave the following definition for multi-scale platforms (citation): "the Commission proposes a definition of online platforms: an undertaking operating in two (or multi)-sided markets, which uses the Internet to enable interactions between two or more distinct but interdependent groups of users so as to generate value for at least one of the groups. Certain platforms also qualify as intermediary service providers" [14]. As the latest definition for the term "electronic platform" is a result of a certain consensus in the international expert community, we will base of this definition.

At the present moment, there is a wide variety of on-line platforms in the market, differing in the intensity of their activity, the chosen sector of business and the business models they use. For example, we can highlight platforms dealing in joint economic activity (Crowdcube, AirBnB, Uber, BlaBlaCar) or market interactions on-line (eBay, Booking.com, Asos, Allegro, Amazon). There are also search engines (Google, Yahoo, Bing) and social networks (Facebook, Twitter), platforms to exchange video (Dailymotion, Vimeo, YouTube), music and video platforms (Deezer, Spotify, Netflix, Canal Play), online gaming (Steam). A legitimate result of such growing variety of platforms is changing the business models for companies, which caused some scholars to characterize such transformation as "platform-based companies" and, according to an evaluation for 2016, there were 135 companies with the capitalization above USD 1 billion and the total volume of capitalization USD 3.7 trillion [15]. A particular feature of the companies who chose electronic platforms to be the basic drivers of their business is quite a fast speed of capitalization, which is confirmed by the data presented in Table 1.

Table 1. Comparative dynamics of indexes for the companies that use E-platforms and those that do not [15]

\begin{tabular}{|c|c|c|c|}
\hline Company & Founded in & Number of employees & $\begin{array}{c}\text { Market capitalization, } \\
\text { USD billion }\end{array}$ \\
\hline BMW & 1916 & 116,000 & 53.0 \\
Uber & 2009 & 7,000 & 60.0 \\
\hline Marriott & 1927 & 200,000 & 17.0 \\
Airbnb & 2008 & 5,000 & 21.0 \\
\hline Walt Disney & 1923 & 185,000 & 165.0 \\
Facebook & 2004 & 12,691 & 315.0 \\
\hline Kodak & 1888 & 145000 & 30.0 \\
Instagram & 2010 & 13 & 1.0 \\
\hline
\end{tabular}

It is noteworthy, that in this table the capitalization for the company Kodak is indicated for its best period, and this company no longer exists. For Instagram its capitalization is for 2012, when it was sold for USD 1 billion; according to the latest data, its capitalization for the year 2017 was evaluated as USD 50 billion [16].

The Organization for Economic Co-operation \& Development (OECD) listed the following basic economic functions of electronic platforms [17]:

- providing the infrastructure for customers and businesses to promote communication and decrease the cost of transactions; 
- collecting, classifying and evaluating information - both for business and customers to decrease the cost of searching;

- promoting social communication and information exchange - to provide customer feed-back;

- ensuring the offer-demand balance - to ensure availability of a wider variety of more relevant goods and better access to the market;

- promoting market processes for better competition between offers due to a wider choice, a better relevance or lower price.

In a recent research prepared for Google, one of the key characteristic of platforms is highlighted - decreasing the asymmetry of information and the possibility to eliminate the price discrimination [18].

Electronic platforms are becoming a more and more important element of the world economy covering more and more sectors - from trade and industry to medical services, culture and education. For example, one of the largest market participants who created possibilities for direct exchange of commodities and information for 35 million legal entities, the company Alibaba Group, in 2012 alone, carried out trade transactions amounting to USD 170 billion. Another company - Dhgate, who also operates on electronic platforms only, trades in 30 million items of commodities in 227 countries for 5 million customers. The company TradeKey exclusively specializes in "connecting" suppliers and customers from 200 countries [19]. Wide possibilities for business are provided by the platforms using block-chain technologies, especially in the bank sector and trade of Crypto currency [20]. The possibilities of platform will be growing, especially considering development of new and innovative technologies - cloud calculations, methods of collecting and processing large volumes of data, quantum calculations.

\section{Electronic platforms and jobs markets}

A wide variety of platforms provides possibilities for diversifying not only the forms of business but also new forms of communication between employers and workers. The most important qualitative change is the possibility for self-employment, like, for example, for driver-partners with the company Uber; another example is the Italian company CoContest specializing in design of interiors [21]. A special review prepared by the European Trade Unions Institute highlights the following cardinal changes that can greatly influence the situation in the jobs market in the conditions of a wide use of electronic platforms [22]:

- flexible possibilities provided by platforms in respect of adapting and re-organizing traditional relationships between employers and workers, for example, in such form as selfemployment;

- remote services, which can potentially lead to off-shoring such services and changing local jobs markets;

- possibility to increase competition due to eliminating barriers, which will definitely affect the conditions of work and payment;

- decreased entrance barriers promote weakening physical barriers between the working and home environment, which can bring risks for health and the moral climate;

- reputation mechanisms used by platforms promote development of the jobs market itself;

- platforms can promote differentiation between types of works depending on their character, to separate between the creative and skilled works and the unskilled works;

- platforms can introduce instability due to non-standard or fake employment.

In a recently published research by Oxford Internet Institute [23] there is a summary of the experience gained by some companies on the Fortune 500 list on hiring freelancers 
through electronic platforms. It is noted that the primary reasons why companies turn to the services provided by platforms are as follows:

- a relatively easy access to a wide jobs market;

- lower cost of transaction;

- shorter time to make contracts at reasonable prices and with good quality of works.

The research also notes that, during 2016 and 2017, the number of projects obtained through these platforms has grown by $26 \%$, the most of them being for such works as: software development, design, texts writing and editing.

Electronic platforms as a new element of the economic system is differently comprehended by new businesses and those who have a long history of work in traditional markets. This, in particular, was confirmed by a research dealing with development of platforms and businesses [24]. It notes the importance to support co-ordination between information systems of the companies and the electronic platforms. As this co-ordination requires certain investment, the companies using traditional forms of doing business are very reluctant in taking such solutions. On the other hand, new companies devote less attention to financial risks, with the focus on finding new and reliable partners.

\section{Conclusion}

Electronic platforms greatly accelerate economic processes and can ensure high decentralization of decision-making on the part of customers and manufacturers. Essentially, a new type economy is being born to function on new architectural principles. As yet, electronic platforms are mainly directed towards service providing, but it can be expected that processing industry will undergo significant structural changes as the platforms are developed. In this regard, finding new forms of co-operation between business and employees is becoming a topical scientific and practical task. The approaches described in this article summarize the accumulated experience. However, more complicated tasks still remain to be solved, including these two key tasks:

- decreasing the asymmetry of information and price discrimination can promote quicker development of business;

- creating a new type of employer-employee relations based on digital platforms and directed not only to development of business but also to protection of social and economic interests of employees.

\section{References}

1. McKinsey Global Institute, Digital Globalization: The New Era Of Global Flows [online], Available at: http://www.mckinsey.com/business-functions/digitalmckinsey/our-insights/digital-globalization-the-new-era-of-global-flows (2016)

2. J. Constine, Facebook now has 2 billion monthly users... and responsibility [online], Available at: https://techcrunch.com/2017/06/27/facebook-2-billion-users/(2017)

3. K.C. Laudon, The Future of Global and North American E-commerce 2006-2011 [online], Available

at: https://www.cti.gov.br/sites/default/files/slides the future_of_global_and_north_ameri can e-commerce.pdf (2006)

4. Worldwide Retail and Ecommerce Sales: eMarketer's Estimates for 2016-2021. eMarketer Report eMarketer [online], Available at: https://www.emarketer.com/Report/Worldwide-Retail-Ecommerce-Sales-eMarketersEstimates-20162021/2002090(2017) 
5. UPS Pulse of the Online Shopper. A customer experience. A UPS Consultation paper. Europe Study. [online], Available at: https://www.ups.com/media/en/gb/OnlineComScoreWhitepaper.pdf (2015)

6. G. Petropoulos, Policy Contribution, 5 (2017)

7. 90 Amazing Uber statistics [online], Available at: https://expandedramblings.com/index.php/uber-statistics/

8. J.V. Hall, A. B. Krueger, An Analysis of the Labor Market for Uber's Driver-Partners in the United States [online], Available at: https://s3.amazonaws.com/uberstatic/comms/PDF/Uber_Driver-Partners_Hall_Kreuger_2015.pdf (2015)

9. L.F. Katz, A.B. Krueger, The Rise and Nature of Alternative Work Arrangements in the United States, 1995-2015 [online], Available at: http://www.nber.org/papers/w22667.pdf (2016)

10. C. Vollmer, Network Technology Revolution [online], Available at: http://jobenomicsblog.com/wp-content/uploads/2014/11/Network-TechnologyRevolution-7-Nov-20141.pdf (2014)

11. D. S. Evans, R. Schmalensee, Competition Policy International, 3(1) (2007)

12. J.C. Rochet, J. Tirole, Two-Sided Markets: An Overview [online], Available at: http://web.mit.edu/14.271/www/rochet tirole.pdf (2004)

13. A. Hagiu, J. Wright, Multi-Sided Platforms (Harvard Business School, Harvard, 2015)

14. Consultation on Regulatory environment for platforms, online intermediaries, data and cloud computing and the collaborative economy'. European Commission [online], Available at: https://ec.europa.eu/digital-single-market/en/news/results-publicconsultation-regulatory-environment-platforms-online-intermediaries-data-and (2015)

15. M. Van Alstyne, Platform Shift: How New Biz Models Are Changing the Shape of Industry [online], Available at: $\underline{\text { http://chairgovreg.fondation- }}$ dauphine.fr/sites/chairgovreg.fondationdauphine.fr/files/attachments/161103_Van\%20Alstyne_Marshall.pdf (2015)

16. V. S. Chauhan, FB Stock: Facebook Inc. (FB) Owned Instagram Could Be Worth Over $\$ 50$ Billion [online], Available at: https://amigobulls.com/articles/2017-04-18-fbstock-facebook-inc-fb-owned-instagram-could-be-worth-over-50-billion (2017)

17. The economic and social role of Internet intermediaries. OECD [online], Available at: https://www.oecd.org/internet/ieconomy/44949023.pdf (2010)

18. Benefits of online platforms. www.oxera.com [online], Available at: https://www.oxera.com/getmedia/84df70f3-8fe0-4ad1-b4ba-d235ee50cb30/Thebenefits-of-online-platforms-main-findings-(October-2015).pdf.aspx? ext=.pdf (2015)

19. S. Sharif, Top 10 B2B Platforms to Help your Business Grow Worldwide [online], Available at: https://www.digitaldoughnut.com/articles/2017/july/b2b-platforms-tohelp-your-business-grow-globally (2017)

20. K. Shiba, Newsletter, 3 (2017)

21. I. Maselli., B. Fabo, Digital workers by design? An example from the on-demand economy, CEPS Working Document 414, Brussels, Centre for European Policy Studies [online], Available at: https://ideas.repec.org/p/eps/cepswp/11030.html (2015)

22. J. Drahokoupil, B. Fabo, ETUI Policy Brief, 5 (2016)

23. G. F. Corporaal, V. Lehdonvirta, Platform Sourcing. How Fortune 500 Firms Are Adopting Online Freelancing Platforms. Oxford Internet Institute. University of Oxford [online], Available at: https://www.oii.ox.ac.uk/publications/platformsourcing.pdf (2017) 
24. D. Truong, M. Bhuiyan, Journal of Entrepreneurship, 13 (2009) 